\title{
ЭПИДЕМИОЛОГИЯ САХАРНОГО ДИАБЕТА В КИРОВСКОЙ ОБЛАСТИ: АНАЛИЗ ДАННЫХ РЕГИСТРА ЗА 5 ЛЕТ
}

\author{
Елсукова О.С., Жуковец Г.В., Соболев А.А.
}

Региональный эндокринологический чентр КОГБУЗ «Кировская клиническая больница №7 им. В.И. Юрловой», Киров

ЦЕЛЬ: изучить динамику эпидемиологических показателей сахарного диабета (СД) в Кировской области за 5-летний период по данным регистра СД.

МАТЕРИАЛЫ И МЕТОДЫ: проведен анализ данных регистра за 5-летний период с 2014 по 2019 гг., проведена статистическая обработка показателей.

РЕЗУЛЬТАТЫ: распространенность СД на 100 тыс. населения в 2014 г. составила 3888,4, в 2019 г. 4311,7 в зависимости от типа СД, выявлен также прирост распространенности СД типа 1 с 153,6 на 100 тыс. населения в 2014 г. до 170,1 в 2019 г. (+21\%). Выявлено, что темпы прироста распространенности СД типа 2 были высокими: от 2714,2 в 2014 г. до 4891,6 в 2019 г. (+80\%). При изучении гендерных особенностей выявлено, что среди пациентов с СД типа 1 в 2014 г. было 51,4\% мужчин и 48,6\% женщин, в 2019 г. - 55\% мужчин и 45\% женщин. Среди пациентов с СД типа 2 преобладают женщины: в 2014 г. — 72,8\% в 2019 - 71,8\%. Заболеваемость СД в 2014 г. составила 281,2 на 100 тыс. населения, в 2019 г. - 442,6 на 100 тыс. населения (+57\%). Пик заболеваемости СД 2 типа в 2014 г. приходился на возраст 56,4 года у мужчин и 59,5 года у женщин, в 2019 г. - пик заболеваемости пришелся на возраст 57,13 года у мужчин и 60,13 года у женщин. Максимальная заболеваемость СД типа 1 выявлена в возрасте 5-9 лет и 21-23 года как в 2014 г., так и в 2019 г. Продолжительность жизни пациентов с СД в 2014 г. составила: мужчин с СД типа 1 54,3 года, женщин с СД типа 1 - 43,0 года, мужчин с СД типа 2 - 69,6 года, женщин с СД типа 2 - 75,3 года. Продолжительность жизни пациентов с СД в 2019 г. составила: мужчин с СД типа 1 - 54,2 года, женщин с СД типа 1 - 68,5 года, мужчин с СД типа 2 - 70,1 года, женщин с СД типа 2 - 77,2 года. Выявлена тенденция к увеличению продолжительности жизни мужчин с СД типа 1 и значительное увеличение продолжительности жизни женщин с СД типа 2. Смертность в 2014 г. составила 198 на 100 тыс., в 2019 г. 290 на 100 тыс., при анализе причин смертности выявлено, что у 41\% умерших пациентов установлена причина смерти как смерть по причине хронической сердечной недостаточности, острого инфаркта миокарда.

ВЫВОДЫ: в Кировской области выявлен неуклонный рост заболеваемости и распространенности СД. Основной вклад в эпидемиологию вносит СД типа 2. Выявлены особенности структуры СД типа 2 - преобладание женщин. Анализируя частоту СД типа 2, выявлено, что в течение 5 лет возраст пациентов с впервые выявленным СД типа 2 составляет 55-59 лет - трудоспособный возраст, что, возможно, связано с активными мероприятиями по скринингу СД среди населения Кировской области. Эпидемиологические показатели СД типа 1 существенно не изменились. Сохраняется высокая смертность пациентов СД, основными причинами смерти установлены сердечно-сосудистые заболевания. Новая версия Регистра СД позволяет оперативно оценить данные эпидемиологии СД. 